Research, part of a Special Feature on Nudging Evolution? Critical Exploration of the Potential and Limitations of the Concept of Institutional Fit for the Study and Adaptive Management of Social-Ecological Systems

\title{
Applying the Concept of Fit to Water Governance Reforms in South Africa
}

\author{
Elke Herrfahrdt-Pähle ${ }^{1}$
}

\begin{abstract}
The call for a spatial fit between institutional arrangements and the resource they manage is reflected in such water management paradigms as river basin management and in a number of international agreements (e.g., the European Union Water Framework Directive). Consequently, a number of countries are currently introducing river basin management, which, besides management along hydrological boundaries, has recently come to include such aspects of governance as stakeholder participation and policy integration. Beginning with a discussion of the goals and limitations of river basin management, this paper describes how the concept has been implemented in South Africa - a country that has been lauded for its state-of-the-art water legislation, but whose water administration is currently struggling to implement it. The example begins by showing the limitations of focusing on the dimension of spatial fit: a perfect spatial fit in basin management is almost impossible owing to the nature of the resource and to social and economic requirements. There are trade-offs between the identification of hydrological boundaries (which sometimes proves difficult) and "boundaries" of social organization, such as a feasible size for effective management, meaningful stakeholder participation, and financial viability. Furthermore, the improved spatial fit of the institutional arrangement and water resource boundaries causes problems of interplay by increasing the need for coordination and cooperation among water management organizations at different levels and on different scales. The example then considers the relevance of other dimensions of water management. It shows that, besides the focus on spatial fit, there is a need to recognize major defining features or boundaries to the problem other than hydrological boundaries, such as those imposed by water service infrastructure (functional fit) and impacts of climate change (dynamic fit), and a need to acknowledge the political and economic dimensions of water management.
\end{abstract}

Key Words: boundaries; dynamic fit; river basin management; South Africa; spatial fit; water governance; water resource management

\section{INTRODUCTION}

The use of hydrological boundaries as a tool for water management and planning has a long history in water resource management (Molle 2006 and 2009). The congruence of resource management institutions with the biogeophysical properties of the resource they seek to manage has recently come to be termed "spatial fit" (Young 2002). Where the reference is to river basin management or catchment management, the suggestion is that river basins are the appropriate governance unit for water resources (Global Water Partnership 2000). The spread of integrated water resource management since the 1990s and its focus on the management of rivers (and other bodies of water) along hydrological boundaries has done a great deal to encourage basin management. In line with the integrated water resource management approach, river basin management has increasingly been conflated with such aspects of governance as participation and integration (Cohen and Davidson 2011). This broader understanding of basin management is reflected in many national and international agreements and policy documents, such as Agenda 21 and the European Union's Water Framework Directive (European Parliament 2000, Moss 2012, Moss 2007).

South Africa has been internationally lauded for incorporating integrated water resource management and basin management into its latest water legislation (Ashton et al. 2006). The end of the apartheid era in 1994 and the democratization process thereafter served as a window of opportunity. The ANC-led Government of National Unity identified water as a key issue in the construction of the postapartheid state (Swatuk 2009). The systematic review of the status quo showed that there was no consistent national approach to water management, the majority of the population was excluded from access to safe drinking water and sanitation, and the water management regime was far from sustainable. To overcome these shortcomings and be in line with the overarching goals of democratic South Africa, the government decided to adopt a decentralized, effective, efficient, equitable, and environmentally sustainable water governance regime (Department of Water Affairs and Forestry 1997). These goals are reflected, for example, in the establishment of Water User Associations, which require the participation of all water users (including historically disadvantaged individuals and women) and the introduction of the ecological reserve, i.e., the reservation of water for environmental flows (Republic of South Africa 1998). This approach was very much in line with the main international discourse on integrated water resource management and such themes as basic human and ecological needs, ecosystem management, and the involvement of nonstate actors (Gleick 2000). One of the major institutional changes brought about by the new South African legislation is the introduction of river basin management as the main approach to managing water (Department of Water Affairs and Forestry 1997, Republic of South Africa 1998).

After providing a brief discussion of the concept of fit and its goals and application in the water sector, I examine the application of the concept of spatial fit (i.e., the introduction of basin management and particularly Catchment Management Agencies) in South African water governance. Our discussion focuses on two questions: how far do current reforms serve to enhance the spatial fit of the social and ecological systems, and how appropriate is the concept of spatial fit to efficient and sustainable water management? I conclude with some thoughts on the future

'German Development Institute /

Deutsches Institut für Entwicklungspolitik (DIE) 
development of South Africa's water governance reforms aimed at achieving equitable, financially viable, and ecologically sustainable resource use. I also argue for the recognition of such other dimensions as functional and dynamic fit.

\section{METHODS}

The results presented are based on research undertaken as part of the NeWater project (New Approaches to Adaptive Water Management under Uncertainty, 2005-2009), which was funded by the 6th EU Framework Programme and sought to shed light on, and facilitate changes to, adaptive strategies for integrated water resource management.

The research consisted of a literature review and field research. During the field research in South Africa, empirical data were gathered with the help of 31 semistructured interviews and five group discussions with farmers, water managers, and scientists and by means of participatory observations of meetings, of committees for the local and regional coordination of water allocation for example. Respondents included representatives of governmental water management agencies at all levels and representatives of other government departments with responsibility for water issues (e.g., agriculture), farmers' associations, water-user associations, NGOs, international and basin water management organizations, and donor agencies. Water users (e.g., farmers) and scientists active in the fields of water management, governance, and climate change were also interviewed. The research was carried out in Johannesburg and Pretoria (national level) and in the Upper Orange Water Management Area, more specifically in and around Bloemfontein in the Free State (provincial and local level). The qualitative data were analyzed using the Atlas.ti software, which allowed the data to be structured and grouped according to codes (e.g., capacity, cooperation) and code families (e.g., institutional change).

\section{APPROACHES TO THE CONCEPTS OF FIT, INTERPLAY, AND SCALE}

The fit between the social and ecological systems and the interplay of institutions and organizations have been identified as important elements when it comes to increasing the resilience of social-ecological systems (Folke 2006, Folke et al. 2007, Galaz et al. 2008). Resilience is defined as "the capacity of a system to absorb disturbance and reorganize while undergoing change so as to still retain essentially the same function, structure, identity, and feedbacks" (Walker et al. 2004). In contrast, others take an effectiveness approach, measuring the effectiveness of river basin management in terms of improved water allocation, improved water quality, a reduction of disputes over water, and an increase in the basin's economic performance (Young 2002, Kemper et al. 2010). Young identifies the concept of fit as a means of increasing the effectiveness of natural resource management and its ability to deal with undesirable environmental change. He further assumes that the effectiveness of management increases as the fit between the properties of the ecological system and the properties of the social system, and especially of institutions, becomes closer (Young 2002). Institutions are defined here as "the rules of the game in a society; more formally, they are the humanly devised constraints that shape human interaction" (North 1997). Both the effectiveness and the resilience approach assume positive effects of an improvement in the fit between institutional arrangements and ecosystem properties. However, in a context of global environmental change and its implications for water availability, framing the issue in terms of resilience seems more comprehensive.

The interaction between institutions has been termed interplay (Young 2002, Pahl-Wostl 2006). Horizontal interplay is the interaction (coordination, cooperation, but also conflict) among institutions and organizations situated at the same jurisdictional level, such as the local level (e.g., water management, spatial planning). Vertical interplay, on the other hand, is associated with the interaction among institutions and organizations at different levels of a scale. The jurisdictional scale, for example, usually consists of the local, provincial, and national levels.

Sets of institutions or institutional arrangements - such as those determining how water should be allocated in a catchment - form the governance structure (Saleth and Dinar 2004, Hatfield-Dodds et al. 2007). Water governance thus sets the operating rules for water management(Pahl-Wostl et al. 2011). The latter is concerned with applying these settled social rules or institutions (for example, distributing water in the catchment) and operationalizing the vision, i.e., with the practical aspects of water allocation (Folke et al. 2005, Jonker et al. 2010). Water management is thus about analyzing, monitoring, developing, and implementing measures to provide water services and protect water resources (Twin2Go 2011).

\section{Dimensions of the concept of fit}

The concept of fit can be categorized in various ways, for example in a spatial or functional sense, depending on the properties of both the resource and the institutional arrangements chosen for the analysis (Cash et al. 2006, Cumming et al. 2006, Folke et al. 2007). Spatial fit refers to the matching of resource boundaries and institutional regimes governing them (Young 2002). Because jurisdictional boundaries do not usually follow the logic of ecosystem boundaries, they often give rise to spatial mismatches (Young 2002). A lack of spatial fit is associated with poor resource management results, because institutions that cover only part of the resource may ignore or have negative external effects (Moss 2007). This may be the case, for example, where the geographical area in which the natural resource is found is not the same as that covered by the resource management institution (Borowski et al. 2008). One possible result of such geographic mismatches is the overuse and pollution of water resources and the consequent loss of the social system's adaptive capacity and of the ecological system's resilience. The rationale behind spatial fit is the assumption that, where institutional arrangements and resource boundaries fit, coordination efforts and negative externalities are reduced, with management outcomes thus being improved. The question of spatial fit can also be applied to the match of institutional regime and resource use system (e.g., water management institutions on the one hand and water supply systems and infrastructure on the other).

The problem of fit can be viewed in the functional sense as well. Functional fit relates to the congruence of resource use mechanisms or institutional attributes on the one hand and ecosystem functionality, i.e., the ecosystem properties or functions addressed through them, on the other (Cumming et al. 2006, Ekstrom and Young 2009). A functional mismatch may thus 
occur if water-pricing mechanisms are so designed that they lead to a rate of groundwater use higher than the rate of aquifer recharge.

Accelerating global environmental change reveals yet another dimension of fit: the ability of institutional arrangements to keep pace with these changes and adapt accordingly. Owing to climate change or resource overuse, the properties of ecological systems are changing faster than before. These dynamics of ecosystem change contrast with the no more than slow change in institutional arrangements characterized by path dependencies (Young 2002). The ability to adapt to ecosystem dynamics, also known as adaptive dancing (Gunderson 2003), is here termed dynamic fit.

The requirements of the various dimensions of fit may be consistent with each other, if, for example, the institutional arrangement provides for the monitoring of water availability in a catchment (spatial fit) and allows for water-use rights to be adjusted on the same scale, i.e., in the catchment, according to seasonal availability (functional fit). However, the requirements associated with the dimensions of fit often differ and sometimes contradict each other. This is true, for example, of water infrastructure. On the one hand, water infrastructure needs to be so organized that it provides water and sanitation services for urban and rural settlements (spatial and functional fit within the social system). On the other hand, this is often inconsistent with the requirements of ecosystems and catchments in terms of water availability and quality (spatial and functional mismatch between the social and the ecological systems). In such cases the appropriate properties or dimensions for which fit should be achieved are often difficult to determine, and trade-offs are inevitable.

In the water sector the notion of spatial fit has been largely applied in the move towards river basin management (Moss 2007), while the notions of functional fit and dynamic fit have received less attention. It is our aim to analyze the introduction of river basin management institutions and their implications for the various dimensions of fit.

River basin management: applying the concept of spatial fit in the water sector

The concept of managing water along hydrological boundaries has been discussed for decades, if not centuries (Molle 2006). Historically, however, water administrative units have often been organized along jurisdictional boundaries even though river basins seldom obey this administrative logic. Jurisdictional boundaries are the product of political, economic, and cultural factors, often sidelining ecological considerations (Young 2002). South Africa, for example, shares three of its major rivers (the Orange-Senqu, Limpopo, and Inkomati) with neighboring countries. As a result, the properties of institutional arrangements governing water resources often do not fit ecosystem properties (the trend towards establishing transboundary river basin organizations addresses this mismatch). It has been suggested that a spatial mismatch encompasses inefficiency and inequitable water use as well as conflicting and contradictory competencies of the managing agencies (Jaspers 2003). Where, for example, a river basin stretches across three provinces, three provincial departments are responsible for water allocation and management along the river. In this situation it is difficult to address upstream-downstream conflicts, and sustainable water management is often compromised by a lack of cooperation and communication between these departments (Moss 2007).

To resolve these issues, such concepts as integrated water resource management stress the need to take a systems perspective and manage water bodies as single entities (Global Water Partnership 2009). These entities (called catchments or basins) are areas which drain to a common body of water (Kerr 2007). The rationale of introducing basin (or catchment) management is to improve the spatial fit between the resource boundaries and the boundaries of the managing entities and thus avoid frictions in the management of the resource. It is suggested that the coordination of upstream-downstream water use becomes easier and problems of overuse can be avoided if management is in the hands of one organization (Moss 2007). In the U.K., for example, catchment management has proved to have such economic, social, and ecological benefits as improved water quality and flood prevention (Lankford et al. 2007). In recent years, basin management has increasingly been associated with such governance issues as the decentralization of water management and the encouragement of public participation in basin organizations as part of democratic decision making (Griffin 1999, Global Water Partnership 2000, Sabatier et al. 2005, Cohen and Davidson 2011). It is not least because of this conflation that basin management is afflicted with a number of problems. They include the difficulty of defining basins or hydrological boundaries, which results in new requirements regarding cooperation and coordination (the problem of interplay) and the presumed depoliticization of water governance.

\section{Problem of spatial fit: defining hydrological boundaries}

River basins and catchments are enclosed by hydrological boundaries, which follow natural drainage divides, i.e., they enclose areas that drain to a common watercourse (Department of Water Affairs and Forestry 1997, Hellweger and Maidment 1999). Despite this seeming straightforwardness, defining hydrological boundaries has proved difficult in practice for a number of reasons (Cohen and Davidson 2011). First, the mere identification of hydrological boundaries is sometimes difficult (Griffin 1999). Particularly in semiarid environments, hydrological boundaries may turn out to be moving targets. Ephemeral rivers (rivers without a constant flow), for example, put the hydrological-boundary approach to the test. The interaction of groundwater and surface water further blurs hydrological boundaries. Other defining features, such as the size of catchments, population density, and economic activity may also compromise the effective and efficient management of a catchment and so require a departure from the basin approach (Cohen and Davidson 2011).

\section{Problem of interplay: increased complexity of decision making}

The management of water along hydrological boundaries results, of course, in management units that straddle administrative and political boundaries, thus increasing the complexity of decision making (Griffin 1999) and necessitating closer communication and cooperation among districts, provinces, and even countries. In addition, coordination with other sectors that continue to respect administrative boundaries (such as agriculture or domestic water use) is complicated. However, taking the aim of sustainable and integrated water resource management seriously 
under the former institutional arrangements would entail similar costs for cooperation and coordination across sectors and administrative units (Global Water Partnership 2000).

\section{Depoliticization of water governance}

It has often been argued that organizing water management along hydrological boundaries suggests an objectivity that does not really exist and which depoliticizes the political nature of water governance and management issues (Blomquist and Schlager 2005, Warner et al. 2008). Despite applying seemingly indisputable natural boundaries, the basin approach fails to resolve a number of fundamental political questions (Blomquist and Schlager 2005). In particular, the difficulty of determining hydrological boundaries and the need to establish financially viable and socially inclusive river basin organizations leaves considerable room for political decision making and debate. Other political questions to be answered in the process of implementing a basin approach include: who is eligible to participate in stakeholder processes, who is accountable to whom, who are the losers in the process, and are there ways of eliciting their support? Establishing basin organizations inevitably requires the transfer of funds, power, and functions from existing water management agencies, which are therefore less likely to support the process (Griffin 1999). Thus, while basin management appears to address the hydrological scale of water management, its recent conflation with governance topics has introduced political, economic, and social dimensions. In many cases, however, the implications of this development in terms of adapted governance structures are not adequately addressed, as the following example from South Africa shows. It further illustrates how the various dimensions have interacted and produced the current gridlock in the implementation of basin management.

\section{WATER GOVERNANCE REFORMS IN SOUTH AFRICA}

South Africa has a history of centralized, authoritarian, and hierarchical water management along administrative boundaries. After the first democratic elections in 1994 the new leaders were determined to overcome the injustice of the apartheid system and sought to reform the whole legislative system. Besides drawing on the international debate around integrated water resource management, the process of drafting the new legislation was informed by ideas that South African water managers had developed earlier, but had been unable to pursue under apartheid rule (de Coning 2006, Muller 2011). These included basin management, an idea South African water managers had toyed with since the 1980s (van Koppen et al. 2002). However, these ideas materialized only with the emergence, after 1994, of the strong political will to reform and redress former inequities and of the aspiration to devolve power to the lowest appropriate level.

Subsequently, a number of legal documents-such as the Water Supply and Sanitation White Paper (Department of Water Affairs and Forestry 1994), the Constitution (Republic of South Africa 1996), the National Water Policy (Department of Water Affairs and Forestry 1997), the Water Services Act addressing water supply (Republic of South Africa 1997), the National Water Act addressing water management (Republic of South Africa 1998), and the National Water Resources Strategy (Department of Water Affairs and Forestry 2004) — were adopted. The new water governance framework reduced the fragmentation of responsibilities and concentrated control over all water resources in the Department of Water Affairs at the national level. A major goal of the new legislation was to decentralize water management to the basin level (Department of Water Affairs and Forestry 1997). For this purpose 19 Water Management Areas (WMAs) were defined (Department of Water Affairs and Forestry 1999b). Since then, efforts have been made to establish a Catchment Management Agency (CMA) in each of these WMAs.

Today, however, the reform process is at a standstill, particularly with regard to the establishment of CMAs. By 2011 only nine of 19 CMAs had been set up, and only two of those were operational (Department of Water Affairs 2011). The reasons frequently cited for this are the lack of leadership and of social and institutional memory due to a high staff turnover and high institutional uncertainty (Department of Water Affairs 2011, Karar et al. 2011). As a result of the prolonged transformation process and associated uncertainties, concerns about inefficiencies and adverse impacts on water security and water quality have been raised by the government (Department of Water Affairs 2011). In 2007 a programme of institutional realignment was launched with the aim of revisiting reform options and proposing ways forward (Department of Water Affairs 2011). One result of this process was a recommendation to reduce the number of CMAs from 19 to nine, with the 19 WMAs clustered under them (Karar et al. 2011), which was approved in March 2012 (Department of Water Affairs 2012). The following outlines the process of CMA establishment, and implications of the latest events are discussed in terms of the dimensions of fit.

\section{INTRODUCTION OF BASIN MANAGEMENT IN SOUTH AFRICA}

In line with administrative thinking, the Department of Water Affairs has regional offices in each of the nine South African provinces. In addition, the National Water Act provides for the establishment of Water Management Areas (WMAs) along hydrological boundaries and of Catchment Management Agencies (CMAs). CMAs have the task of managing water resources for various uses by coordinating the activities of water users and water management organizations and by promoting community participation in water management (Republic of South Africa 1998). Accordingly, CMAs are conceived as platforms for balancing the interests of farmers, larger privatesector entities, and local and provincial government and environmental interest groups. To this end, CMAs consist of a managing board comprising representatives of all stakeholders in the catchment. The process of establishing a CMA usually starts with a period of awareness raising and stakeholder participation. This can be supported by the formation of a Catchment Forum. The next step may be to set up steering committees to facilitate the process of drafting a CMA establishment proposal (de la Harpe et al. 1999). These processes have often been initiated and supported by the Department of Water Affairs or technical consultants (van Koppen et al. 2002, Brown and Woodhouse 2004). Until proposals are approved and a functioning governing board is established, the Department of Water Affairs regional offices remain in charge of water management.

\section{Defining hydrological boundaries}

To initiate the process of defining WMAs along hydrological boundaries, internal ministerial workshops were held. This 
resulted in the proposal for WMAs (Department of Water Affairs and Forestry 1999b) and was followed by a nationwide consultation process and the publication of the final report in October 1999 (Department of Water Affairs and Forestry 1999a). The definition of hydrological boundaries and thus of catchments proved to be rather challenging in the South African context. First, South Africa has a comprehensive network of (transboundary) water transfer schemes, which connect otherwise distinct basins. Despite these connections, the basins are managed separately (Department of Water Affairs and Forestry 1997). Another cause of concern is the existence of such ephemeral rivers as the Nossob, which makes the definition of boundaries difficult (Seely et al. 2003). The impact of climate change on southern African water resources and particularly on the streamflow of rivers is likely to exacerbate these problems (de Wit and Stankiewicz 2006). Its impact on the runoff and hydrology of South African water resources has already been detected (Boko et al. 2007). The interannual variability of precipitation has increased, resulting in higher rainfall anomalies and more intense and widespread droughts (MacKellar et al. 2007). For the future, climate change models suggest that a $20 \%$ decline in precipitation may lead to a decline of up to $70 \%$ in runoff in some parts of the Orange-Senqu River Basin, which is a major water source for irrigated agriculture (de Wit and Stankiewicz 2006).

Secondly, while the National Water Act requires WMAs to comply with the hydrological principle, it also stipulates that patterns of social and economic development, efficiency, and communal interests are to be taken into account in the definition of boundaries (Republic of South Africa 1998). Accordingly, the Department of Water Affairs made an explicit distinction between catchments (drainage areas) and WMAs (management units, Department of Water Affairs and Forestry 1999b). This provided room for political decision making, politicized the definition of basin boundaries, and led to departures from the basin principle, examples being:

- Dividing a basin into several WMAs where river basins were too large and too difficult to administer with one management body (Jaspers 2003).

- Merging basins in one WMA, if single hydrological units were too small to be financially viable and efficiently managed by a separate agency, which would, among other things, have an adverse effect on their ability to recruit and retain sufficient staff (Waalewijn et al. 2005, Karar et al. 2011)

- Assigning water users to the basin from which they received most water (through transfers), irrespective of the basin in which they were situated.

These examples show that defining catchment boundaries in South Africa was affected by a number of difficulties and, despite its apparent objectivity, involved scientific as well as political decisions (Cohen and Davidson 2011).

\section{Problems of spatial fit and interplay}

Because the designation of the WMAs is (usually) based on hydrological boundaries, CMAs often cut across district and provincial boundaries (James 2003). The Upper Orange Water Management Area, for example, covers parts of three provinces (Free State, Northern Cape, and Eastern Cape). This overlapping makes it difficult to use the three-tiered administrative system (the national, provincial, and municipal levels) in establishing and supporting CMAs. Furthermore, cooperation between water management and other sectors and departments is impeded by the overlapping, because other departments usually focus on such other factors as infrastructure requirements (e.g., water service provision) or on administrative boundaries (e.g., Department of Agriculture, Forestry and Fisheries). The creation of CMAs led to confusion over responsibilities and roles in the process, even in such related departments as Rural Development and Agriculture, which have traditionally had a major say in water provision (Movik 2012).

The complex picture of competencies of organizations at different levels (e.g., province, catchment, and municipality) and in different spheres (e.g., water services and water resource management), and the resulting need for coordinated action, are evident from the following example taken from the Orange River. The river has been divided into the Upper and Lower Orange WMAs, thus revealing the trade-offs between the introduction of basin management and the need to divide the basin into smaller units for practical reasons.

The Department of Water Affairs's regional offices in Bloemfontein (Free State) and Kimberley (Northern Cape) have divisions responsible for water resources management, which will be transferred to the CMAs once the latter are established, and for water services (policies, regulations and support), while responsibility for the actual provision of water services rests with the municipalities. The Department of Water Affairs water resources management division in Bloemfontein is responsible for the Upper Orange WMA, while the Northern Cape Department of Water Affairs regional office in Kimberley is responsible for the Lower Orange WMA. Any problem with river pollution in the Northern Cape and within the Upper Orange WMA is the responsibility of water resources management, because it concerns a river (cf. Fig. 1). In this case, it is not the Department of Water Affairs provincial office (Kimberley - Northern Cape) that is in charge, but the regional office in the neighboring Free State, which is responsible for the Upper Orange WMA. But if there is a problem with drinking water pollution in the same place, it must be addressed by the Department of Water Affairs regional office in Kimberley (Northern Cape), because drinking water issues are dealt with along administrative boundaries. It would not even be the Department of Water Affairs primarily, but the relevant municipality, which is in charge of water services. Similar problems abound with such other sectors as irrigated agriculture which rely on water management, but must also comply with the administrative boundaries.

Another example of the spatial mismatches and costs associated with the introduction of hydrological boundaries is water supply in district municipalities that straddle catchment boundaries and thus belong to more than one catchment area. Municipalities belonging to two different CMAs can draw on water allocation from both. For example, two CMAs are responsible for providing water to the Bushbuckridge district municipality in the Sand River catchment. Theoretically, the municipality must disaggregate 
water-use data according not only to the number of people living in each catchment but also to the amount of water used by each (Pollard and du Toit 2005). This disaggregation entails huge administrative transaction costs. Similarly, although the city of Cape Town obtains its water from a reservoir in the Breede Overberg WMA, it is situated in the Berg River WMA, to which it sends its waste water (Mazibuko and Pegram 2006).

Fig. 1. Mismatch of hydrological and administrative boundaries in the Upper and Lower Orange Water Management Areas (WMAs).

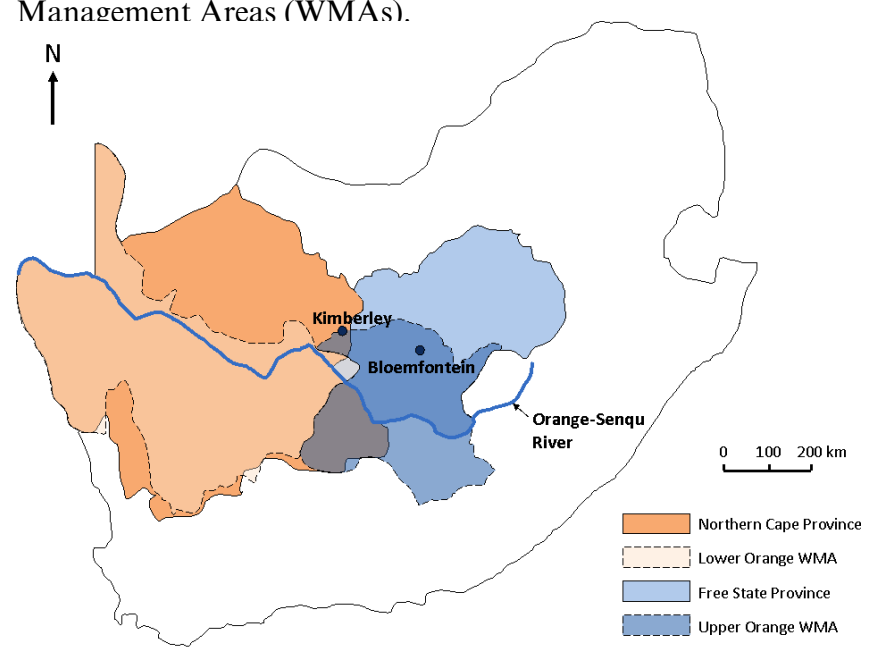

These examples show how the coexistence of hydrological boundaries for water resource management and administrative boundaries for water service provision and the attendant infrastructure requirements increase the complexity of water management. Nevertheless, the spatial fit of CMAs and municipalities is appropriate: it meets the requirements of their respective primary tasks, that of managing a water resource in a CMA's case (i.e., following hydrological boundaries), and that of supplying water to municipalities (i.e., following and fitting administrative boundaries). However, the diverging requirements in terms of spatial fit underline the need for coordination and cooperation (interplay) if resource management is to be effective and resilient.

\section{Dealing with problems of interplay}

The South African constitution underlines the need for cooperative governance among the three tiers of governance, i.e., the levels of national, provincial. and local government (Republic of South Africa 1996). However, it is not clear if or how CMAs are included in this framework. In other words, it seems that little thought has yet been given to mechanisms for communication and coordination between the Department of Water Affairs and the future CMAs. While the CMAs are responsible for water resource management and agricultural water supply, water supply to individual and industrial users is the responsibility of Water Services Authorities (WSAs), i.e., municipalities (Department of Water Affairs and Forestry 2002). Cooperation and communication between WSAs and water resource management agencies (Department of Water Affairs regional offices and CMAs) should be closest, because water management has been largely devolved to that level, which is where most friction occurs. A number of coordination mechanisms are envisaged in policy instruments. For example, WSA allocation plans are required to comply with the contents of the CMA's Catchment Management Strategy (James 2003). Municipalities are obliged to develop Integrated Development Plans, which seek to coordinate different spheres of government and to integrate and harmonize sectoral plans for water, land use, and the environment (Zenani 2006). The part of the Integrated Development Plan that concerns water services is the Water Services Development Plan. It addresses drinking water supply and sanitation and is meant to be based on information provided by the CMA regarding the water available in its area. Demand for other than drinking water (e.g., for irrigated agriculture) is not reflected in the Water Services Development Plans.

These direct linkages between the planning instruments of local government and CMAs are joined by a number of indirect linkages. They include, for example, Spatial Development Initiatives, Economic Development Strategies, and Environmental Implementation Plans (Department of Water Affairs and Forestry 2001, Mazibuko and Pegram 2006) which need to be prepared by local government and affect such water issues as water infrastructure, environmental management, and water allocation plans.

Despite the cooperation requirements described above, a lack of coordination and communication can be detected both within the Department of Water Affairs (between divisions responsible for water services and water resource management) and among the Department of Water Affairs, CMAs, and local government or WSAs (Funke et al. 2007). Specified procedures and rules that guide cooperation between the Department of Water Affairs/ CMAs and local government are not being implemented. Cooperation largely depends upon capacity and levels of understanding of legislation by individuals (Mazibuko and Pegram 2006). The understanding of the interrelatedness of water services and water resource management is poor not only within local government but also within the Department of Water Affairs (Mazibuko and Pegram 2006).

However, the need to coordinate water resource management with water service provision exists irrespective of the perfect spatial fit of the administering agencies. The management of water along administrative boundaries also requires the coordination and cooperation of all actors within a basin if resource overuse and pollution are to be avoided. The mismatch of the boundaries of WSAs and CMAs in the basin management approach merely emphasizes this need for cooperation and probably makes it more difficult.

In South Africa, it is not clear how cooperation should come about. Local government is clearly overburdened with the task, and in most Water Management Areas it will take a few more years until CMAs are established. It is also questionable whether the Department of Water Affairs's regional offices will be able to perform this task, because they have more than enough to do setting up the CMAs (see below, Karar et al. 2011, Muller 2011). Despite these constraints, the Department of Water Affairs is 
currently endeavoring to align and integrate water services and water resource management more closely (Department of Water Affairs 2010).

\section{The political dimensions of catchment management}

Since the promulgation of the National Water Act and related legislation, the political environment in South Africa has changed. Issues of social equity and economic growth have come to the fore, sidelining environmental concerns to some extent (Sabine Stuart-Hill, personal communication). This trend is also reflected in South African water resource management and governance (Department of Water Affairs and Forestry 2009). The Department of Water Affairs is reported to be increasingly neglecting such broader issues as integrated management and instead focusing on access to safe drinking water and sanitation (Jonker et al. 2010). This development is accompanied by the apparent reluctance of the water administration to establish CMAs (Department of Water Affairs 2011). One reason for this reluctance may be the consequent reduction of functions, power, and funds for Department of Water Affairs. At the level of the Department of Water Affairs regional offices, which have the task of establishing the CMAs, a number of factors have led to delays in the reform process. The establishment process has turned out to be very complex and demanding, because it requires extensive processes of stakeholder participation and the creation of a whole set of new organisations and institutions that do not conform to conventional administrative thinking. The staff of the regional offices often comprise engineers and hydrologists who are having to set up CMAs in addition to their ordinary tasks, and rarely with the support of additional manpower or capacity building. They are often overburdened with and ill prepared for the task of institutional development and that of facilitating participation processes (Karar et al. 2011). Furthermore, Department of Water Affairs staff have few incentives to establish CMAs because they are associated with the transfer of staff from the Department of Water Affairs to the CMAs (which entails leaving a secure post in state administration in the provincial capital and sometimes having to move to another town (Department of Water Affairs 2011, Karar et al. 2011). These disincentives, together with such other constraints as limited financial and human resources, have resulted in an extremely slow reform process.

\section{IMPORTANCE OF OTHER DIMENSIONS OF FIT IN SOUTH AFRICA}

As shown above, the issue of spatial fit has received a great deal of attention in the course of South African water reform. However, a number of aspects of functional and dynamic fit appear to be at least as relevant in South Africa's case. The impact of climate change on water resources in particular calls for focus on the other dimensions of fit. A serious problem in the case of functional fit is the continuing overuse of water resources. In such catchments as the Vaal, demand for water resources exceeds supply in terms of both quantity and quality (Department of Water Affairs and Forestry 2004). In the past, the solution to this problem has been to provide more water through extensive basin transfers and the construction of dams. Today, suitable sites for such large-scale infrastructure developments are scarce, as are financial resources.. Furthermore, the impact of climate change on river runoff, precipitation, etc. may render large-scale infrastructure, e.g., dams, as inefficient in the future. In spite of this, many water managers still favor large-scale infrastructure solutions (technical control paradigm, dynamic mismatch).

The problems mentioned above call for a demand management approach to water use. The new water legislation provides for major steps to be taken in this direction, one example being the introduction of a reserve for human and environmental water needs (Republic of South Africa 1998). This has, however, been delayed by technical and political factors.

Recent trends and climate models suggest an increase in the availability of water in the eastern parts of the country and decreasing runoff in the already rather dry west (Midgley et al. 2007). At a time of climate change, hydrological boundaries may also be subject to change, and their usefulness as points of reference may be compromised. For example, perennial rivers with permanent water flows may become ephemeral, the definition of hydrological boundaries thus being compromised, as is currently the case with the River Nossob. In such situations, improved dynamic fit may be needed in the form of flexibility and the ability of institutions and organizations to adapt and increase the resilience of the water governance regime. In South Africa, for example, drought relief is granted once a farmer receives less than half the water he or she has applied for over a period of several years. In a climate change scenario, with highly variable precipitation patterns, farmers may thus be severely affected by droughts and flooding in subsequent years without being eligible for relief. In this case, such institutions as drought relief funds need to be more flexible.

The Working for Water Programme can serve as a positive example for improved dynamic fit. As such invasive alien species as eucalyptus trees absorb much more water than native plants, they are threatening water availability in some South African provinces. By paying for such flora to be eradicated, the Working for Water Programme provides jobs and training for unskilled rural laborers, while reacting to the implications of global change for water resources (Department of Water Affairs and Forestry 2006).

\section{DISCUSSION}

The introduction of river basin management in South Africa has revealed a number of problems associated with spatial fit and the goal of water management along hydrological boundaries. It also provides some insight into the appropriateness of the notion of spatial fit in water resource management in general and the importance of other dimensions of the concept of fit.

\section{Taking stock of river basin management in South Africa: slowly} improving the spatial fit

In South Africa, a window of opportunity for reorganizing water management along hydrological boundaries opened with the end of the apartheid era in 1994. However, as work has proceeded towards the achievement of this ambitious goal, four difficulties have been encountered. First, owing to the nature of water resources, it has proved difficult to determine hydrological boundaries clearly. Second, as the costs associated with some other "boundaries" are higher, compromises have had to be reached between a perfect spatial fit and other practical constraints (financial viability). Third, the establishment of 
CMAs has been delayed by a lack of political will, of the necessary human and financial resources, and of incentives for the staff. Finally, the combination of basin management and other (admittedly important) goals, such as equity and stakeholder participation, has further impeded timely implementation, leading to a stalemate and the revision of reform goals. These difficulties highlight the relevance of other than biogeophysical properties of water management and the political economy of basin management.

Notwithstanding these shortcomings and compared to the former situation, the introduction of CMAs has led to an improved spatial fit between the social and the ecological systems. The reduction of the number of CMAs from 19 to nine will probably lead to the closer alignment of institutional and hydrological boundaries, because the merger of WMAs that belong hydrologically to the same basin is envisaged (e.g., Upper and Lower Orange-Senqu). In a country confronted with water scarcity and water-quality problems, this is an important decision. However, the basin management approach does not relieve water managers of the need to improve coordination and cooperation with other units. It changes the challenge inasmuch as, rather than requiring coordination between upstream and downstream, it now calls for coordination with other departments and sectors. Owing to significant coordination and cooperation deficits, and despite the alignment of boundaries, concerns about efficient and sustainable water management persist (Department of Water Affairs 2011).

If established properly, CMAs have the potential to become bridging organizations, i.e., platforms for building trust, learning, resolution of conflicts, and cooperation across levels and scales (Cash et al. 2006, Olsson et al. 2007). By facilitating processes of identifying the relevant levels and scales of a problem, they improve resource use and management through equitable and sustainable management decisions based on the resource boundaries. This may be a major benefit, given that current discussions in the international arena on resource management underline the importance of recognizing interdependencies and interactions across sectors, also known as the land-water-energy nexus (European Commission 2012). In South Africa, this potential of CMAs could be used to achieve two goals: firstly, to comply with the constitutional call for equitable resource use, participation, and decentralization in the water sector. In this sense, the downscaling of water management to basin level may increase the legitimacy and transparency of water allocation and management and inform and improve decision making. Secondly, however, downscaling to the catchment level will enable enough oversight and control over water management to be retained at the central level. This is particularly necessary in the case of South Africa, which is characterized by water scarcity and highly variable and uncertain water availability.

\section{Taking stock of the dimensions of fit: spatial, functional, or dynamic?}

With its emphasis on hydrological boundaries, water resource management has focused on spatial fit (Global Water Partnership 2009). This suggests that the defining property of water resources is the hydrological boundary. However, the case of South Africa shows that the boundaries of the natural system are at times difficult to determine and are but one factor on which efficient and resilient water management relies.

On the one hand, the introduction of CMAs has improved the spatial fit of water resources with the institutions managing them. On the other, it has produced a number of functional mismatches within the social system, among them being the economic viability of management units and the mismatch of institutions for water resource management on the one hand, and drinking water supply and sanitation on the other. While basin management and spatial fit may be necessary conditions for sustainable and integrated water management, other (adequate) conditions are the functional and dynamic fit dimensions, which are gaining in importance as environmental change accelerates and the flexibility of institutional arrangements becomes more limited owing to path dependency and political realities. In the light of these trends, the perfect fit in hydrological terms may not be the best option, and the best fit is not necessarily the (perfect) spatial fit. In South Africa, the numerous planning instruments used by local government (e.g., Spatial Development Initiatives) that affect the work of CMAs without requiring their involvement in the drafting process may serve as examples. Because there may be scenarios in which the major defining features of the problem are not resource boundaries, some suggest that the reference should be to "problemsheds" rather than watersheds or catchments (Allan 1998, Mollinga et al. 2007). In South Africa, such a problemshed might be framed, for example, around the problem of dealing with decreasing water availability and the increasing occurrence of extreme droughts.

This is not an argument against basin management. Basin management can be an important element in the sustainable management of water resources, but the other dimensions of fit are at least as important. They deserve more attention because they have not been sufficiently studied in the past and because both functional and dynamic fit are gaining in importance in the context of global environmental change. A dynamic understanding of fit requires the strengthening of the link between the social and ecological systems and more flexible, adaptive, and resilient governance regimes (Galaz et al. 2008). One approach to achieving this goal is adaptive governance (Dietz et al. 2003, Folke et al. 2005). Besides increasing institutional flexibility (to adapt legislative frameworks and policies to environmental change), adaptive governance entails systematically increasing the participation of stakeholders (to incorporate local knowledge) as well as multilevel and polycentric governance (to support decentralized decision making and coordination across levels and scales (Folke et al. 2005, Olsson et al. 2006, HerrfahrdtPähle 2012)). The basin management approach is one way of addressing at least some of these elements and may thus help to improve not only the spatial fit but also the dynamic fit. The case of South Africa has, however, highlighted the limitations of addressing all these issues at once in a context of scarce human and financial resources.

\section{CONCLUSION}

The case of South Africa illustrates the importance of the different dimensions of fit, the consequences of their application for the administrative units directly and indirectly concerned, and the resulting additional coordination needs. It firstly shows that 
there is a need to recognize major defining features other than spatial fit and hydrological boundaries, such as functional fit (for example imposed by water service infrastructure) and dynamic fit (for example the growing dynamics of environmental change and particularly climate change and their implications for the availability of water resources). Secondly, the South African case study illustrates the importance of the political and economic dimensions of water management. Thirdly, it underlines the relevance of the interplay of various institutions and organizations involved in efficient and sustainable water management in and outside the water sector. In some cases, for example, this process of deliberation may result in the identification of water quality as another major defining feature in the catchment, an insight that may lead to the responsibility for water quality issues being concentrated in one organization (increased functional fit) rather than being shared by several, depending on the source and place of the pollution (as the example of the Upper Orange WMA has shown).

Problems of spatial fit and interplay as well as trade-offs between the different dimensions of fit are inevitable in the water sector and among water management and other organizations owing to the many layers of water governance. The advantages of basin management cannot be exploited until the lack of attention to governance issues and problems of interplay associated with the introduction of basin management in the broader sense-i.e., coordination issues within the water sector (as among divisions of the Department of Water Affairs) and between the newly established CMA and other organizations (e.g., local government and agriculture-have been corrected. In South Africa, for example, guidelines are needed to determine the relationship, coordination, and cooperation between the Department of Water Affairs and CMAs and among CMAs. These problems of interplay can be remedied only by a high degree of inter- and intra-organizational coordination - a requirement that South African water management organizations struggling with a brain drain, a lack of financial resources and a high turnover of staff will have difficulty in meeting. In this context of scarce human and financial resources, disentangling basin management from other policy objectives (Cohen and Davidson 2011), such as equitable representation and participation and a sequenced approach, may be more realistic and help to preclude resentment about slow progress. This raises the question whether overly ambitious aims as regards both an improved spatial fit and the coupling of issues of spatial fit with issues of equitable access and participation may not weaken reform processes and make them prone to a backlash.

However, regardless of resource endowment, these kinds of transformations of water governance regimes are likely to take a long time. Their effectiveness and success should therefore be measured over decades rather than years (Department of Water Affairs 2011, Kemper et al. 2010). It may thus be too early to judge and call for alternative solutions or even revert to former management approaches. Rather than questioning reform objectives (as currently observed in South Africa), this calls for efforts to restore political will, reduce uncertainties, define priorities for action, focus limited resources on pressing issues, and mobilize staff support. It seems particularly important at present to avoid any further increase in uncertainty, which may accompany any move to reduce the number of CMAs. The way forward in this process (regarding the status of existing CMAs, for example, and naming those that have to be merged) should be swiftly communicated to provide a clear roadmap for the future.

Responses to this article can be read online at: http://www.ecologyandsociety.org/issues/responses. $\mathrm{php} / 5964$

\section{Acknowledgments:}

The author wishes to thank Andreas Thiel, Katherine Farrell, Synne Movik, Gül Ozerol, and two anonymous reviewers for their constructive feedback and comments on earlier versions of this paper.

\section{LITERATURE CITED}

Allan, T. 1998. Watersheds and problemsheds: explaining the absence of armed conflict over water in the Middle East. Middle East Review of International Affairs 2(1):49-51.

Ashton, P. J., A. R. Turton, and D. J. Roux. 2006. Exploring the government, society, and science interfaces in integrated water resource management in South Africa. Journal of Contemporary Water Research \& Education 135(1):28-35. http://dx.doi. org/10.1111/j.1936-704X.2006.mp135001004.X

Blomquist, W., and E. Schlager. 2005. Political pitfalls of integrated watershed management. Society and Natural Resources 18:101-117. http://dx.doi.org/10.1080/08941920590894435

Boko, M., I. Niang, A. Nyong, C. Vogel, A. Githeko, B. OsmanElasha, R. Tabo, and P. Yanda. 2007. Africa. Pages 433-468 in M. L. Parry, O. F. Canziani, J. P. Palutikof, P. J. Van der Linden, and C. E. Hanson, editors. Climate change 2007: impacts, adaptation and vulnerability: contribution of Working Group II to the Fourth Assessment Report of the Intergovernmental Panel on Climate Change. Cambridge University Press, New York, New York, USA.

Borowski, I., J.-P. Le Bourhis, C. Pahl-Wostl, and B. Barraqué. 2008. Spatial misfit in participatory river basin management: effects on social learning: a comparative analysis of German and French case studies. Ecology and Society 13(1):7. [online] URL: http://www.ecologyandsociety.org/vol13/iss 1/art7

Brown, J., and P. Woodhouse. 2004. Pioneering redistributive regulatory reform: a study of implementation of a catchment management agency for the Inkomati Water Management Area, South Africa. CRC Working Paper 89/200. Centre on Regulation and Competition, Manchester, UK. http://dx.doi. org/10.4337/9781847203076.00019

Cash, D. W., N. W. Adger, F. Berkes, P. Garden, L. Lebel, P. Olsson, L. Pritchard, and O. Young. 2006. Scale and cross-scale dynamics: governance and information in a multilevel world. Ecology and Society 11(2):8. [online] URL: http://www.ecologyandsociety. org/vol11/iss $2 /$ art 8

Cohen, A., and S. Davidson. 2011. The watershed approach: challenges, antecedents, and the transition from technical tool to governance unit. Water Alternatives 4(1):1-14. 
Cumming, G. S., D. H. M. Cumming, and C. L. Redman. 2006. Scale mismatches in social-ecological systems: causes, consequences, and solutions. Ecology and Society 11(1):14. [online] URL: http://www.ecologyandsociety.org/vol11/iss1/ $\underline{\operatorname{art} 14}$

de Coning, C. 2006. Overview of the water policy process in South Africa. Water Policy 8(6):505-528. http://dx.doi.org/10.2166/ wp.2006.039

de la Harpe, J., J.-A. Ferriera, and A. Potter. 1999. Water management institutions overview. Department of Water Affairs and Forestry, Republic of South Africa, Pretoria, Gauteng Province, South Africa.

Department of Water Affairs. 2010. Strategic overview of the water sector in South Africa 2010. DWA Directorate: Water Services Planning \& Information, Republic of South Africa, Pretoria, Gauteng Province, South Africa.

Department of Water Affairs. 2011. Institutional reform and realignment: a strategic framework for institutional realignment and reform. Republic of South Africa, Pretoria, Gauteng Province, South Africa.

Department of Water Affairs. 2012. Minister establishes nine (9) Catchment Management Agencies. Press release. Republic of South Africa, Pretoria, Gauteng Province, South Africa.

Department of Water Affairs and Forestry. 1994. Water-an indivisible national asset. Water supply and sanitation policy white paper. Republic of South Africa, Pretoria, Gauteng Province, South Africa.

Department of Water Affairs and Forestry. 1997. White paper on a national water policy for South Africa. Republic of South Africa, Pretoria, Gauteng Province, South Africa.

Department of Water Affairs and Forestry. 1999a. Establishment of the Water Management Areas and their boundaries as a component of the National Water Resource Strategy in terms of Section 5(1) of the National Water Act (Act No. 36 of 1998). Government Gazette, Republic of South Africa, Pretoria, Gauteng Province, South Africa.

Department of Water Affairs and Forestry. 1999b. The water management areas of South Africa: catchment management report. Republic of South Africa, Pretoria, Gauteng Province, South Africa.

Department of Water Affairs and Forestry. 2001. Development of a generic framework for a catchment management strategy. Final draft. Republic of South Africa, Pretoria, Gauteng Province, South Africa.

Department of Water Affairs and Forestry. 2002. Water is life, sanitation is dignity. Draft white paper on water services/Draft for public comment. Pretoria, Gauteng Province, South Africa.

Department of Water Affairs and Forestry. 2004. Internal strategic perspective for the Vaal river system overarching. DWAF Report No. P RSA C000/00/0103. Directorate National Water Resource Planning, Republic of South Africa, Pretoria, Gauteng Province, South Africa.
Department of Water Affairs and Forestry. 2004. National water resource strategy: "our blue print for survival". First edition. Republic of South Africa, Pretoria, Gauteng Province, South Africa.

Department of Water Affairs and Forestry. 2006. Working for water information pamphlet. Republic of South Africa. [online] URL: http://www.dwaf.gov.za/wfw/

Department of Water Affairs and Forestry. 2009. Water for growth \& development framework. Version 7. Republic of South Africa, Pretoria, Gauteng Province, South Africa.

de Wit, M., and J. Stankiewicz. 2006. Changes in surface water supply across Africa with predicted climate change. Science 311 (5769):1917-1921. http://dx.doi.org/10.1126/science.1119929

Dietz, T., E. Ostrom, and P. C. Stern. 2003. The struggle to govern the commons. Science 302(5652):1907-1912. http://dx.doi. org/10.1126/science.1091015

Ekstrom, J. A. and O. R. Young. 2009. Evaluating functional fit between a set of institutions and an ecosystem. Ecology and Society 14(2):16. [online] URL: http://www.ecologyandsociety. org/vol14/iss $2 / \operatorname{art} 16$

European Parliament. 2000. Directive 2000/60/EC of the European Parliament and of the Council of 23 October 2000 establishing a framework for Community action in the field of water policy. [Water Framework Directive]. European Commission, Brussels, Belgium.

European Report on Development. 2012. Confronting scarcity: managing water, energy and land for inclusive and sustainable growth, European Report on Development. Overseas Development Institute (ODI), European Centre for Development Policy Management (ECDPM), German Development Institute/ Deutsches Institut für Entwicklungspolitik (GDI/DIE), and the European Union, Belgium.

Folke, C. 2006. Resilience: the emergence of a perspective for social-ecological systems analyses. Global Environmental Change 16(3):253-267. http://dx.doi.org/10.1016/j.gloenvcha.2006.04.002

Folke, C., T. Hahn, P. Olsson, and J. Norberg. 2005. Adaptive governance of social-ecological systems. Annual Review of Environment and Resources 30:441-473. http://dx.doi.org/10.1146/ annurev.energy.30.050504.144511

Folke, C., L. Pritchard, F. Berkes, J. Colding, and U. Svedin. 2007. The problem of fit between ecosystem and institutions: ten years later. Ecology and Society 12(1):30. [online] URL: http://www. ecologyandsociety.org/vol12/iss1/art30

Funke, N., S. H. H. Oelofse, J. Hattingh, P. J. Ashton, and A. R. Turton. 2007. IWRM in developing countries: lessons from the Mhlatuze catchment in South Africa. Physics and Chemistry of the Earth 32:1237-1245. http://dx.doi.org/10.1016/j.pce.2007.07.018

Galaz, V., P. Olsson, T. Hahn, C. Folke, and U. Svedin. 2008. The problem of fit between ecosystems and governance systems insights and emerging challenges. Pages 15-16 in O. Young, L. A. King, and H. Schroeder, editors. Institutions and environmental change: principal findings, applications, and research frontiers. MIT Press, Boston, Massachusetts, USA. 
Gleick, P. H. 2000. The changing water paradigm: a look at twenty-first century water resources development. Water International 25(1):127-138.

Griffin, C. B. 1999. Watershed councils: an emerging form of public participation in natural resource management. Journal of the American Water Resources Association 35(3):505-518. http:// dx.doi.org/10.1111/j.1752-1688.1999.tb03607.x

Gunderson, L. H. 2003. Adaptive dancing: Interactions between social resilience and ecological crises. Pages 33-52 in F. Berkes, J. Colding, and C. Folke, editors. Navigating social-ecological systems: building resilience for complexity and change. Cambridge University Press, Cambridge, UK. http://dx.doi.org/10.1017/ CBO9780511541957.005

Global Water Partnership. 2000. Integrated water resources management. Global Water Partnership, Stockholm, Sweden.

Global Water Partnership. 2009. A handbook for integrated water resources management in basins. Global Water Partnership, Stockholm, Sweden; and International Network of Basin Organizations, Paris, France.

Hatfield-Dodds, S., R. Nelson, and D. C. Cook. 2007. Adaptive governance: an introduction, and implications for public policy. Australian Agricultural and Resource Economics Society, 2007 Conference (51st), February 13-16, 2007, Queenstown, New Zealand.

Hellweger, F. L., and D. R. Maidment. 1999. Definition and connection of hydrological elements using geographic data. Journal of Hydrologic Engineering 4(1):10-18. http://dx.doi. org/10.1061/(ASCE)1084-0699(1999)4:1(10)

Herrfahrdt-Pähle, E. 2012. The South African water sector: on its way towards adaptive water governance? Pages 79-100 in W. Leal Filho, editor. Climate change and the sustainable use of water resources. Springer, Berlin, Germany.

James, A. J. 2003. Institutional challenges for water resources management: India and South Africa. WHIRL Project Working Paper 7. Water, Households \& Rural Livelihoods, a joint Indian, South African \& UK project co-ordinated by the Natural Resources Institute (NRI), University of Greenwich, Chatham Maritime, Kent, UK.

Jaspers, F. 2003. Institutional arrangements for integrated river basin management. Water Policy 5:77-90.

Jonker, L. E., L. A. Swatuk, M. Matiwane, U. Mila, M. Ntloko, and F. Simataa. 2010. Exploring the lowest appropriate level of water governance in South Africa. WRC Report No. 1837/1/10. Water Research Commission, Pretoria, South Africa.

Karar, E., G. Mazubuko, T. Gyedu-Ababio, and D. Weston. 2011. Catchment management agencies: a case study of institutional reform in South Africa. Pages 145-164 in B. Schreiner and R. Hassan, editors. Transforming water management in South Africa: designing and implementing a new policy framework. Springer, London, England. http://dx.doi.org/10.1007/978-90-481-9367-7_ 7

Kemper, K. E., W. Blomquist, and A. Dinar, editors. 2010. Integrated river basin management through decentralization. Springer, Berlin, Germany. http://dx.doi.org/10.1007/978-3-540-28355-3
Kerr, J. 2007. Watershed management: lessons from common property theory. International Journal of the Commons 1:89-109.

Lankford, B. A., D. J. Merrey, J. Cour, and N. Hepworth. 2007. From integrated to expedient: an adaptive framework for river basin management in developing countries. Research Report 110. International Water Management Institute, Colombo, Sri Lanka.

MacKellar, N. C., B. C. Hewitson, and M. A. Tadross. 2007. Namaqualand's climate: recent historical changes and future scenarios. Journal of Arid Environments 70:604-614. http://dx.doi. org/10.1016/j.jaridenv.2006.03.024

Mazibuko, G., and G. Pegram. 2006. Evaluation of the opportunities for cooperative governance between catchment management agencies and local government. 1433/1/06, Water Research Commission, Gezina, South Africa.

Midgley, G., R. Chapman, P. Mukheibir, M. Tadross, B. Hewitson, S. Wand, R. Schulze, T. Lumsden, M. Horan, M. Warburton, B. Kgope, B. Mantlana, A. Knowles, A. Abayomi, G. Ziervogel, R. Cullis, and A. Theron. 2007. Impacts, vulnerability and adaptation in key South African sectors: an input into the long term mitigation scenarios process. Energy Research Center, Cape Town, South Africa.

Molle, F. 2006. Planning and managing water resources at the riverbasin level: emergence and evolution of a concept. International Water Management Institute, Colombo, Sri Lanka.

Molle, F. 2009. River-basin planning and management: the social life of a concept. Geoforum 40:484-494. http://dx.doi.org/10.1016/ j.geoforum.2009.03.004

Mollinga, P. P., R. S. Meinzen-Dick, and D. J. Merrey. 2007. Politics, plurality and problemsheds: a strategic approach for reform of agricultural water resources management. Development Policy Review 25:699-719. http://dx.doi.org/10.1111/

j.1467-7679.2007.00393.x

Moss, T. 2007. Solving problems of 'fit' at the expense of problems of 'interplay'? The spatial reorganisation of water management following the EU Water Framework Directive. Pages 64-108 in P. P. Mollinga, A. Dixit, and K. Athukorala, editors. Integrated water resources management: global theory, emerging practice and local needs. Sage Publications, New Delhi, India.

Moss, T. 2012. Spatial Fit, from Panacea to Practice: Implementing the EU Water Framework Directive. Ecology and Society 17(3):2. http://dx.doi.org/10.5751/ES-04821-170302

Movik, S. 2012. Fluid rights: water allocation reform in South Africa. Human Sciences Research Council, Pretoria, South Africa.

Muller, M. 2011. Lessons from South Africa about the management and development of water resources from inclusive and sustainable growth. European Report on Development. Overseas Development Institute, Deutsches Institut für Entwicklungspolitik, and the European Centre for Development Policy Management.

North, D. C. 1997. The contribution of the New Institutional Economics to an understanding of the transition problem. UNU World Institute for Development Economics Research, Helsinki, Finland. 
Olsson, P., C. Folke, V. Galaz, T. Hahn, and L. Schultz. 2007. Enhancing the fit through adaptive co-management: creating and maintaining bridging functions for matching scales in the Kristianstads Vattenrike Biosphere Reserve, Sweden. Ecology and Society 12(1):28. [online] URL: http://www.ecologyandsociety. org/vol12/iss $1 /$ art28

Olsson, P., L. H. Gunderson, S. R. Carpenter, P. Ryan, L. Lebel, C. Folke, and C. S. Holling. 2006. Shooting the rapids: navigating transitions to adaptive governance of social-ecological systems. Ecology and Society 11(1):18. [online] URL: http://www. ecologyandsociety.org/vol11/iss1/art18

Pahl-Wostl, C. 2006. The importance of social learning in restoring the multifunctionality of rivers and floodplains. Ecology and Society 11(1):10. [online] URL: http://www.ecologyandsociety. org/vol11/iss 1/art10

Pahl-Wostl, C., L. Lebel, C. Knieper, and T. D'Haeyer, editors. 2011. D. 2.3: synthesis report: context-sensitive comparative analysis of associations between water governance properties and performance in water management. Version 3, updated in August 2012. Twin2Go, Osnabrück, Lower Saxony, Germany.

Pollard, S., and D. du Toit. 2005. Achieving integrated water resource management: the mismatch in boundaries between water resources management and water supply. Paper presented at International workshop on African water Laws: Plural Legislative Frameworks for Rural Water Management in Africa, Johannesburg, South Africa .Co-organised by the International Water Management Institute, the Natural Resources Institute of the University of Greenwich, the Faculty of Law of the University of Dar-es-Salaam, and the South African Department of Water Affairs and Forestry.

Republic of South Africa. 1996. Constitution of the Republic of South Africa. Pretoria, Gauteng Province, South Africa.

Republic of South Africa. 1997. Water Services Act, 1997. Government Gazette, Cape Town, Republic of South Africa.

Republic of South Africa. 1998. National Water Act - Act No 36 of 1998. Pretoria, Gauteng Province, South Africa.

Sabatier, P. A., W. Focht, M. Lubell, Z. Trachtenberg, A. Vedlitz, and M. Matlock. 2005. Collaborative approaches to watershed management. Pages 3-22 in S. Kamieniecki and M. E. Kraft, editors. Swimming upstream: collaborative approaches to watershed management. MIT Press, Cambridge, Massachusetts, USA.

Saleth, R. M. and A. Dinar. 2004. The institutional economics of water. Edward Elgar, Washington, D.C., USA. http://dx.doi. org/10.1596/0-8213-5656-9

Seely, M., J. Henderson, P. Heyns, P. Jacobson, T. Nakale, K. Nantanga, and K. Schachtschneider. 2003. Ephemeral and endoreic river systems: Relevance and management challenges. Pages 187-212 in A. Turton, P. Ashton, and E. Cloete, editors. Transboundary rivers, sovereignty and development: hydropolitical drivers in the Okavango River basin. African Water Issues Research Unit, Centre for International Political Studies, Pretoria, Gauteng Province, South Africa.
Swatuk, L. A. 2009. The state and water resources development: a tale of two South Africas. Water Alternatives 3(3):521-536.

Twin2Go. 2011. Responding to climate change: towards more adaptive water governance systems. Policy Brief 1. Osnabrück, Lower Saxony, Germany.

van Koppen, B., N. Jha, and D. J. Merrey. 2002. Redressing racial inequities through water law in South Africa: interaction and contest among legal frameworks. Paper presented at the Commons in an Age of Globalisation: The Ninth Biennial Conference of the International Association for the Study of Common Property, Victoria Falls, Zimbabwe, June 17-21, 2002. International Water Management Institute Africa Regional Program.

Waalewijn, P., P. Wester, and K. van Straaten. 2005. Transforming river basin management in South Africa: lessons from the lower Komati River. Water International 30:184-196. http://dx.doi. org/10.1080/02508060508691859

Walker, B., C. S. Holling, S. R. Carpenter, and A. Kinzig. 2004. Resilience, adaptability and transformability in social-ecological systems. Ecology and Society 9(2):5. [online] URL: http://www. ecologyandsociety.org/vol9/iss $2 /$ art5

Warner, J., P. Wester, and A. Bolding. 2008. Going with the flow: river basins as the natural units for water management? Water Policy 10:121-138.

Young, O. 2002. The institutional dimensions of environmental change. MIT Press, Cambridge, Massachusetts, USA.

Zenani, V. 2006. Institutional dimensions of water resource management in South Africa: socio-cultural perspectives: a case study of the Keiskamma - Umzimvubu Water Management Area (WMA 12). University of Cape Town, Cape Town, South Africa. 